\title{
TECHNICAL SCIENCE
}

\section{Green environmental risk management in the projects of transport enterprises using foresight methods}

\author{
O. O. Bakulich, I. R. Kis \\ National Transport University, Kyiv, Ukraine \\ Corresponding author. E-mail: bakulich.elena@gmail.com; Arinakiss.23@gmail.com
}

Paper received 29.08.20; Accepted for publication 16.09.20.

https://doi.org/10.31174/SEND-NT2020-238VIII29-10

\begin{abstract}
The article is devoted to the study of green environmental risk management in the projects of transport enterprises using foresight methodology as an element of strategic management. The features of green risk management introduction in projects of transport enterprises are considered. The necessity of risk management concepts in projects is determined (taking into account current trends in the greening of economic activity of industrial enterprises). The implementation of proactive risk management as a green is proposed. It involves a forecasting of their characteristics and a forming of a strategic program, which provides for the development of measures not only to protect the environment from their impact, but also to prevent their occurrence. There are two main models in green business: incentive models and life cycle models. Incentive models include functional systems for selling or servicing goods, and design, construction, finance, operation, etc. Also incentive models may contain performance-based models that can have environmental effects, implemented as energy saving companies, water conservation companies, material saving companies and chemical management systems. Life cycle models include take-back system, Green Supply Chain (GSC) and industrial symbiosis. A lot of business organizations use different types of green business models and innovations to support the overall green business model. Thus, their green business model innovations intersect and reinforce each other, based on business approaches aimed at the renewable value of materials. Under the Kyoto Protocol, there is a mechanism called the Clean Development Mechanism. A business organization in a developing country has to implement an emission reduction project that aims to achieve the goals of the Kyoto Protocol to promote environmental sustainable development.

Green business management methods are often characterized by the following statements:

1. They include environmental criteria in all main business decisions;

2. They supply environmentally friendly goods or services, whenever possible;

3. Business is clearly concerned about the impact on the environment;

4. Business is committed to the long-term application of environmental criteria in its daily activity.

An important aspect is the addition of the «3R» principle in the practice of doing business. The Three R's - (reduced, reuse, and recycle) principle involves the reduction, reuse and disposal of waste.

Keywords: risks; environmental risks; risk management; project; transport enterprises.
\end{abstract}

Introduction. The modern economic activity of enterprises is characterized by numerous and rapid changes in the external environment, which also have significant consequences for internal changes. One of the trends is to understand the impact of business on the environment. Also it is important to determine not only the reduction of the negative impact on the environment, but also identify the increase of the positive impact as a strategic priority of the enterprises functioning. This aspect is one of the most diverse strategies for sustainable business development. Given those same factors, the issues of green environmental risk management in the projects of transport enterprises need to be worked out.

Literature review. The study of green enterprise management was conducted by both native and foreign scientists. Issues of ecological modernization were dealt with by $\mathrm{O}$. Shkarupa [1] and others. Mohamed Elias Ezanee, Santhirasegaran Nadarajan, Mahidin Norlila [2], Seidel S. and Recker J. [3], Fernando Y., Walters T., Ismail M.N., Seo Y.W. and Kaimasu M. [4] also paid attention to the issue of green business management. Different aspects of "green logistics" were studied in the works of Byrne, P., Deeb, A. [5], Janbo, L., Songxian, L. [6], Murphy, P.R., Braunschweig, R.F., Charles, D. [7]. O. Levkivsky, V. Zyuzyun, F. Ploshay [8], O. Danchenko [9], V. Zanora [10; 11] devoted their works to the study of risk management.

Forecasting techniques were considered by Derek Barker, David J.H. Smith [12], Linstone H.A. [13], Halabi A.X., Montoya-Torres J.R., Obregón N. [14], Kwakkel J.H., Pruyt E. [15].
The subject of O. Shkarupa's [1] research is the management of ecological modernization of socio-ecological development of the region and enterprises in a certain context. Mohamed Elias Ezanee, Santhirasegaran Nadarajan, Mahidin Norlila [2] considered the practices of green management and green supply chain, focusing on the experience of manufacturing enterprises. Seidel S., \& Recker J. [3] analyzed the features of the introduction of green business processes in the organizations within the context of the information system functionality importance. Fernando Y., Walters T., Ismail M.N., Seo Y.W. and Kaimasu M. [4] explored that the project risk management and the green supply chain management have a positive impact on the project management results and its success.

Byrne P. and Deeb A. [5] paid attention to the development of green logistics. They noted that the requirements for its greening were growing. The forms of environmental logistics were considered by Janbo L. and Songxian L. [6]. Murphy P.R., Braunschweig R.F. and Charles D. [7] conducted a comparative analysis of approaches to the active, moderate or conservative implementation of green logistics.

O. Levkivsky, V. Zyuzyun, F. Ploshay [8] developed an approach based on the formation of a map-scheme of environmental risk management in different projects of the petroleum products transportation by road. They paid attention to the decomposition of the system into subsystems and the identification of risks at all stages. O. Danchenko [9] focused her research on the thorough elaboration of various risk management aspects. V.Zanora [10; 11] considered the inte- 
grated risk management of the enterprise and the features of expert analysis of risks level.

Purpose. The purpose of the article is to study the features of green environmental risk management in the transport enterprises projects using foresight methods.

Materials and methods. Such scientists as O. Levkivsky, V. Zyuzyun, F. Ploshay [8] emphasized the importance and significance of the researched issues in their works. They noted that, for example, harmful emissions from vehicles in Kyiv alone reach $90 \%$ of total emissions from all sources of environmental pollution. The total amount of harmful substances generated by cars registered in the capital is about 2.1 million tons per year. Also there should be added the pollution of soil and reservoirs with used oils from the motor transport infrastructure enterprises, spillage of petroleum products and waste from washing cars; cluttering of the area with such transport waste as rubber tires, discarded batteries, metal parts, etc [8].

The authors [8] also identified the main aspects of solving the researched issue. They paid attention to the improvement, development and working out of risk management methods in the program of transport activities greening projects. Today, the reference point for the functioning of transport enterprises is the formation of a management system focused on a sustainable development.

The development of the economic activity must be strategically planned to make it stable. That's why, there is a strategic management. Fernando Y., Walters T., Ismail M.N., Seo Y.W. and Kaimasu M. [4] consider that the effective implementation of green supply chain management (GSCM) and risk reduction strategies are strategic solutions for managing of sustainable project efficiency and successful project realisation.

One of the strategic management components is a strategic planning, based on forecasting. Forecasting is nothing more than an attempt to look into the future in order to determine the economic activity prospects. Western management theory and practice defines forecasting technology more broadly, as a "Foresight" methods.

Ben Martin [16] described foresight as a systematic attempt to assess the long-term prospects of science, technology, economics and society to determine the strategic research and new technologies directions, which are able to bring the greatest socio-economic benefits.

The "Foresight" method was further developed, and in the early 1980s a national foresight critical technology project was launched in the United States. One of its main tasks is to determine development priorities.

The expert evaluation is carried out within the methods. This is done by involving experts to determine assessments, such as alternatives to the enterprise development, the feasibility of its projects. One of the main conditions of the project success is the use of methods that ensure the effective work of the experts involved [17]. It should be admitted that the use of methods that ensure the effective experts work is sufficient only in the case of their appropriate qualifications.

As it is noted in [10] with reference to [18] expert (from Latin "expertus" - experienced) is a person, who has a practical experience in the field of the expertise. Other people usually ask the expert for estimates and forecasts of the certain decisions results. The qualification of the expert should be determined taking into account several criteria, namely theoretical knowledge, characterized by the presence of special- ized education and work experience. The positive experience of working with an expert is a confirmation of his ability to predict [10].

The expert risk assessment is a subjective conclusion about the risks after their study and analysis [19]. The limitations of expert review, as noted in [10], include requirements consisting in ensuring the minimum cost of funds for the examination, the minimum amount of time, as well as the maximum level of confidence in the experts.

Results and discussion. The technology of the enterprise economic activity green management for its sustainable development involves compliance with its principles in all areas such as risk management. One of these principles is the reappraisal of the human capital and environment value to conduct business.

The enterprises must be ready not only to comply with stricter requirements of the environmental legislation, which is only a matter of time, but also to become the initiators of a conscious attitude to the environment. This is already a real condition for ensuring the competitiveness of business in the near future, bearing in mind Ukraine's aspirations to join the European Union, where this practice is gaining momentum.

There are two main models in green business: incentive models and life cycle models. Incentive models include functional systems for selling or servicing goods, and design, construction, finance, operation, etc. Also incentive models may contain performance-based models that can have environmental effects, implemented as energy saving companies, water conservation companies, material saving companies and chemical management systems. Life cycle models include take-back system, Green Supply Chain (GSC) and industrial symbiosis. A lot of business organizations use different types of green business models and innovations to support the overall green business model. Thus, their green business model innovations intersect and reinforce each other, based on business approaches aimed at the renewable value of materials [3].

Under the Kyoto Protocol, there is a mechanism called the Clean Development Mechanism, which is defined in Article 12. A business organization in a developing country has to implement an emission reduction project that aims to achieve the goals of the Kyoto Protocol to promote environmental sustainable development [20].

Green business management methods are often characterized by the following statements [2]:

1. They include environmental criteria in all main business decisions;

2. They supply environmentally friendly goods or services, whenever possible;

3. Business is clearly concerned about the impact on the environment;

4. Business is committed to the long-term application of environmental criteria in its daily activity.

An important aspect is the addition of the $« 3 R »$ principle in the practice of doing business. The Three R's - (reduced, reuse, and recycle) principle involves the reduction, reuse and disposal of waste.

So as it is proved in the work [4], risk management is a factor, the availability and effectiveness of which have a positive impact on the effectiveness of the project and its success. The transition from traditional risk management to green involves a change of the conceptual framework. One of the green risk management elements of transport enter- 
prises projects should be the formation of a program that will contain proposals to improve the enterprise economic activity in the context of environmental impact. The risk analysis phase needs to be worked out. The risk analysis should be based on recognized methods, in particular, foresight methods. Also it should be carried out taking into account the supplemented principles of green risk management. The correctness of the risks analysis and the obtained results is an important aspect of green risk management, as it is a basis for a proactive response to risks. At the same time, it should be noted that green management is strategic, as it involves the development of a strategy. It also is long-term and include subsequent decomposition into operational and tactical components.

Therefore, the sequence of green risk management of transport enterprises projects should include: identification of risks, which also includes the use of foresight methods to predict their impact taking into account a certain period of time; proactive risk management, which involves the for- mation of a program of measures to minimize the impact of risks not only to an acceptable level at the moment, but to the maximum possible level if risk is not avoided.

Conclusions. According to the results of the study, the need for forecasting was determined in order to ensure the strategy of transport enterprises economic activity sustainable development, which includes green risk management of their projects.

It was proposed to use "Foresight" methods as a method of combined forecasting. It is a comprehensive tool for prioritizing the results of the analysis. The features of expert evaluation used in forecasting methods are determined.

Green risk management of projects is characterized by proactivity and involves improving the stage of risk identification and its forecasting. The general concept of risk management is also changing. One of its main priorities today is not just to minimize risks to a certain acceptable level, but at best to avoid those risks which have a negative impact on the environment.

\section{REFERENCES}

1. Шкарупа O.B. Управління екологічною модернізацією соціально-екологічного розвитку регіону // Economic AnnalsXXI, 2015. №7-8(2). C. 57-60.

2. Mohamed Elias Ezanee, Santhirasegaran Nadarajan, Mahidin Norlila. Green business management and green supply chain practises: a case study in a manufacturing organization // Journal of technology management, 2013. Vol. 8, № 1. P. 1-19.

3. Seidel, S. \& Recker, J. Implementing Green Business Processes: The Importance of Functional Affordances of Information System // Australia: 23rd Australasian Conference on Information Systems, 2012

4. Fernando, Y., Walters, T., Ismail, M.N., Seo, Y.W. and Kaimasu, M. «Managing project success using project risk and green supply chain management: A survey of automotive industry» // International Journal of Managing Projects in Business, 2018. Vol. 11, No. 2. P. 332-365. https://doi.org/10.1108/IJMPB-012017-0007.

5. Byrne, P., Deeb, A. Logistics must meet the 'green' challenge // Transportation and Distribution, 1993. P. 33-35.

6. Janbo, L., Songxian, L. The Forms of Ecological Logistics and Its Relationship Under the Globalization // Ecological Economy, 2008. №4. P. 290-298.

7. Murphy, P.R., Braunschweig, R.F., Charles, D. Green logistics: Comparative views of environmental progressives, moderates, and conservatives // Journal of Business Logistics, 1996. №1. P. $87-102$.

8. Левківський О.П., Зюзюн В.І., Плошай Ф.В. Розробка методики управління ризиками в програмах і проектах екологічно безпечної транспортної діяльності (на прикладі Київської міської програми «Екологія транспорту»)//Управління проектами, системний аналіз і логістика, 2012. Вип. 10.

9. Данченко О.Б., Занора В.О. Проектний менеджмент: управління ризиками та змінами в процесах прийняття управлін- ських рішень : монографія. Черкаси, 2019. 278 с.

10. Занора В.О. Експертний метод аналізу ризиків промислового підприємства // Управління проектами та розвиток виробництва, 2011. №2(38). С. 95-101.

11. Занора В.О., Войтко С.В. Управління підприємствами: планування технологічних витрат, ризик-менеджмент, мотивування, прийняття управлінських рішень : монографія. Київ : КПІ ім. Ігоря Сікорського, Вид-во «Політехніка», 2017. 224 c.

12. Derek Barker, David J.H. Smith. Technology foresight using roadmaps // Long Range Planning, 1995. №28, (2). P. 21-28.

13. Linstone, H.A. Three eras of technology foresight // Technovation, 2011. Vol. 31, is. 2. P. 69-76.

14. Halabi, A.X., Montoya-Torres, J.R., Obregón, N. A case study of group decision method for environmental foresight and water resources planning using a fuzzy approach // Group Decision and Negotiation, 2012. Vol. 21, is. 2. P. 205-232.

15. Kwakkel, J.H., Pruyt, E. Exploratory Modeling and Analysis, an approach for model-based foresight under deep uncertainty // Technological Forecasting and Social Change, 2013. Vol. 80, is. 3. P. 419-431. https://doi.org/10.1016/j.techfore.2012.10.005.

16. Martin, B. Research Foresight and the exploitation of science base. HSMO, London, 1993.

17. Семенова Н.Н. Форсайт в условиях глобализации // Информационное общество, 2008. № 3-4. С. 112-125.

18. Сидельников Ю.В. Теория и организация экспертного прогнозирования. М.: ИМЭМО РАН, 1990. 196 с.

19. Грабовецький Б.С. Економічне прогнозування і планування: навч. посібник. К.: Центр навчальної літератури, 2003. 188 с.

20. United Nation. Clean Development Mechanism. 2015. Available at: http://unfccc.int/kyoto_protocol/mechanisms/ clean_development_mechanism/item s/2718.php.

\section{REFERENCES}

1. Shkarupa, O. Management of region's social and economic development environmental modernization. Economic Annals-XXI (2015), 7-8(2), 57-60.

8. Levkivskiy, A.P., Ziuziun, V.I., Ploshay, F.V. Development methods of risk management in the project of oil transportation by road // Management of projects, system analysis and logistics, 2012. Vol. 10.

9. Danchenko, O.B., Zanora, V.O. (2019). Project Management: Risk and Change Management in Decision Making Processes. Cherkasy: Chabanenko, $278 \mathrm{p}$.

10. Zanora, V.O. Expert method of industrial enterprise risks analy- sys // Project management and production development, 2011. №2(38). P. 95-101.

11. Zanora, V.O., Voitko, S.V. (2017). Enterprise management: technological costs planning, risk management, motivation, management decisions making. Kyiv: Politekhnika, 224 p.

17. Semenova, N.N. Foresight in conditions of globalization // Information society, 2008. № 3-4. P. 112-125.

18. Sidelnikov Yu.V. Theory and organization of expert forecasting. M.: IMEMO RAN, 1990. $196 \mathrm{c}$.

19. Grabovetsky B.E. Economic forecasting and planning. K.: Center for Educational Literature, 2003. 188 c. 